\title{
Retrospective analysis of fish community change during a half-century of landuse and streamflow changes
}

Author(s) :Keith B. Gido, Walter K. Dodds, and Mark E. Eberle

Source: Journal of the North American Benthological Society, 29(3):970-987. 2010.

Published By: North American Benthological Society

DOI: $10.1899 / 09-116.1$

URL: http://www.bioone.org/doi/full/10.1899/09-116.1

BioOne (www.bioone.org) is a nonprofit, online aggregation of core research in the biological, ecological, and environmental sciences. BioOne provides a sustainable online platform for over 170 journals and books published by nonprofit societies, associations, museums, institutions, and presses.

Your use of this PDF, the BioOne Web site, and all posted and associated content indicates your acceptance of BioOne's Terms of Use, available at www.bioone.org/page/terms_of_use.

Usage of BioOne content is strictly limited to personal, educational, and non-commercial use. Commercial inquiries or rights and permissions requests should be directed to the individual publisher as copyright holder. 


\title{
Retrospective analysis of fish community change during a half- century of landuse and streamflow changes
}

\author{
Keith B. Gido ${ }^{1}$ AND Walter K. Dodds ${ }^{2}$ \\ Division of Biology, Ackert Hall, Kansas State University, Manhattan, Kansas 66506 USA \\ Mark E. Eberle ${ }^{3}$ \\ Department of Biological Sciences, Fort Hays State University, Hays, Kansas 67601 USA
}

\begin{abstract}
Ecological thresholds that lead to alternative community states can be exceeded through gradual perturbation or as a result of sudden disturbance. Many Great Plains streams have experienced dramatic changes in their hydrologic regime resulting from water and landuse changes that began as early as 1880 . These changes, combined with the presence of many invasive species, have substantially altered the fish communities in this area. We quantified temporal changes in fish communities in 3 large river basins in relation to putative anthropogenic stressors, including increased sediment supply derived from row-crop agriculture (beginning in 1880), habitat fragmentation caused by reservoir construction (beginning in the 1950s), and reduced discharge caused by groundwater withdrawal (beginning in the 1960s). We hypothesized that these abiotic regime shifts, coupled with species invasions, would shift the system from a fish community dominated by lotic (flowing water) species to one dominated by lentic (still water) species. Further, we predicted that the timing and intensity of community change would vary across basins that experienced different types and levels of stressors. Restructuring of fish communities across the 3 river basins was driven primarily by similar increases in lentic species, with only a few declines in several large-river species. Current fish communities in these basins share $<50 \%$ of the species recorded in historic collections, and these differences were driven by species extirpations and invasions. The greatest levels of community divergence over time occurred in western Kansas basins that experienced the most intense groundwater withdrawals and fragmentation by reservoirs. An alarming result from this analysis was the recent (after 1991) expansion of several invasive species in the Arkansas and lower Kansas River basins and the decline or extirpation of several native species where flow regimes are less heavily altered. Accelerating changes in the biota and habitat identified by our retrospective analysis highlight potential complications for restoring the habitat and native fish communities to a previous state.
\end{abstract}

Key words: biotic homogenization, retrospective analysis, invasive species, hydrology, presence-absence data, streamflow modification.

Characterizing long-term trajectories of ecological systems aids conservation efforts by identifying potential drivers of change and targets for restoration. For example, many systems show abrupt changes in structure at a particular point along an environmental gradient, or changes in structure might be gradual because of a time-lagged response or a gradually accumulating stressor. What appears to people to be a gradual change could be abrupt relative to the evolutionary history of species being considered.

\footnotetext{
${ }^{1}$ E-mail addresses: kgido@ksu.edu

2 wkdodds@ksu.edu

3 meberle@fhsu.edu
}

One example would be species with long life spans that can persist in an area but not reproduce. In many cases where habitats have been drastically altered, distinguishing natural vs imposed changes on communities is difficult because baseline data on community variability are not available. Moreover, the spatial and temporal scales of data collection are not typically designed to test explicitly for those changes. Thus, creative ways of retrospectively analyzing available data could provide necessary information for conservation of highly imperiled faunas, such as freshwater stream organisms that have been heavily impacted by human activities (Dudgeon et al. 2006, Jelks et al. 2008). Compounding these uncertainties is 
a weak understanding of linkages between alterations of stream habitats and biota because multiple stressors occur simultaneously.

Responses of native fishes to environmental modifications might be gradual because species are adapted to find refugia from disturbances in systems with a high degree of spatial and temporal heterogeneity (Humphries and Baldwin 2003). Thus, stream organisms that evolved under nonequilibrium conditions might be insensitive or slow to respond to relatively major changes in abiotic ecosystem drivers (Schlosser 1987). If biotic changes develop slowly in response to persistent modifications to the environment, it could be difficult to link changes in community structure with alterations of the system given typical temporal scales of observation. Groundwater withdrawals probably fall into this category because of the gradual shrinking of the aboveground stream network. Alternatively, community composition of streams could be tightly linked to natural system dynamics (Poff and Allan 1995, Poff et al. 1997, Lytle and Poff 2004) and might respond rapidly to alteration. Construction of a dam, possibly associated with the introduction of nonnative species, is an example of a potentially abrupt transition that could result in a rapid response in the system, especially on a local scale, including the decline of some native lotic species and the increase in nonnative species (Baxter 1977, Kinsolving and Bain 1993, Lytle and Poff 2004).

We used a retrospective analysis to evaluate spatial and temporal trends in human activities and their association with changes in species richness and fish community structure. We contrasted changes in fish communities in 3 major river basins across 4 periods between 1947 and 2003. The periods were selected based on available data on fish communities and our ability to establish its coincidence with the onset of major alterations to stream habitats or to account for time-lagged responses to those alterations. We predicted that native fish species dependent upon freeflowing streams have declined regionally because of fragmentation by dams, and that native and nonnative fishes that favor nonflowing systems have increased over time. We predicted strong, time-lagged responses to these changes because of the large spatial scale of our analysis and heterogeneity of stream networks. However, the magnitude of effects and time lags are likely to vary with different types of stressors. For example, once an invasive species arrives in an area, it might expand rapidly (e.g., Koehn 2004), whereas deterioration of native fishes because of groundwater withdrawal might be more prolonged. In addition, change in fish communities was expected to be greatest in western Kansas basins because of the combined loss of habitat through groundwater withdrawals and the impacts from impoundments.

Our data are specific to prairie streams in North America, but these types of anthropogenic stressors involving landscape transformation, impoundments, groundwater mining, and the introduction of nonnative species are common worldwide. Globally, the need for restoration and mitigation of future impacts increases as streamflow regimes continue to be altered by dams (Nilsson et al. 2005, Poff et al. 2007), land use (Hascic and Wu 2006, Scott 2006), and water withdrawals (Hauer and Lorang 2004, Nilsson et al. 2005, Deacon et al. 2007). Using retrospective analysis to link mechanisms directly to changes is difficult, but improving our ability to use historical data might help us evaluate the impact of changes caused by human alteration on the functioning of aquatic ecosystems and project future changes to these systems.

\section{Methods}

\section{Study area}

Long-term changes in fish communities were evaluated across 2 basins in western Kansas and 1 basin in eastern Kansas (Fig. 1). The upper Arkansas River and Smoky Hill River basins in western Kansas are influenced by the High Plains (Ogallala) Aquifer and have experienced dramatic reductions in flow associated with groundwater withdrawals and increased fragmentation by impoundments. The lower Kansas River in eastern Kansas represents streams that have experienced modest changes in flow quantity, but have many reservoirs that regulate flows and have fragmented stream networks. Environmental data collected from streams in these basins and surrounding basins in Kansas are distributed along climatic gradients that are typical of the Great Plains. From west to east, average annual precipitation in Kansas increases from $\sim 350 \mathrm{~mm}$ to $\sim 1270 \mathrm{~mm}$ (based on data from 1971-2000; Kansas State University Weather Data Library, www.oznet.ksu.edu/wd/). As potential precipitation increases from west to east, the density of streams with perennial flows increases and the proportion of groundwater contributing to streamflow diminishes.

\section{Landuse, hydrologic, and climate data}

To quantify changes in land use, data were assembled from the US Department of Agriculture National Agricultural Statistics Service (http:/ / www. nass.usda.gov/QuickStats/) and the Interuniversity Consortium for Political and Social Research (ICPSR; 


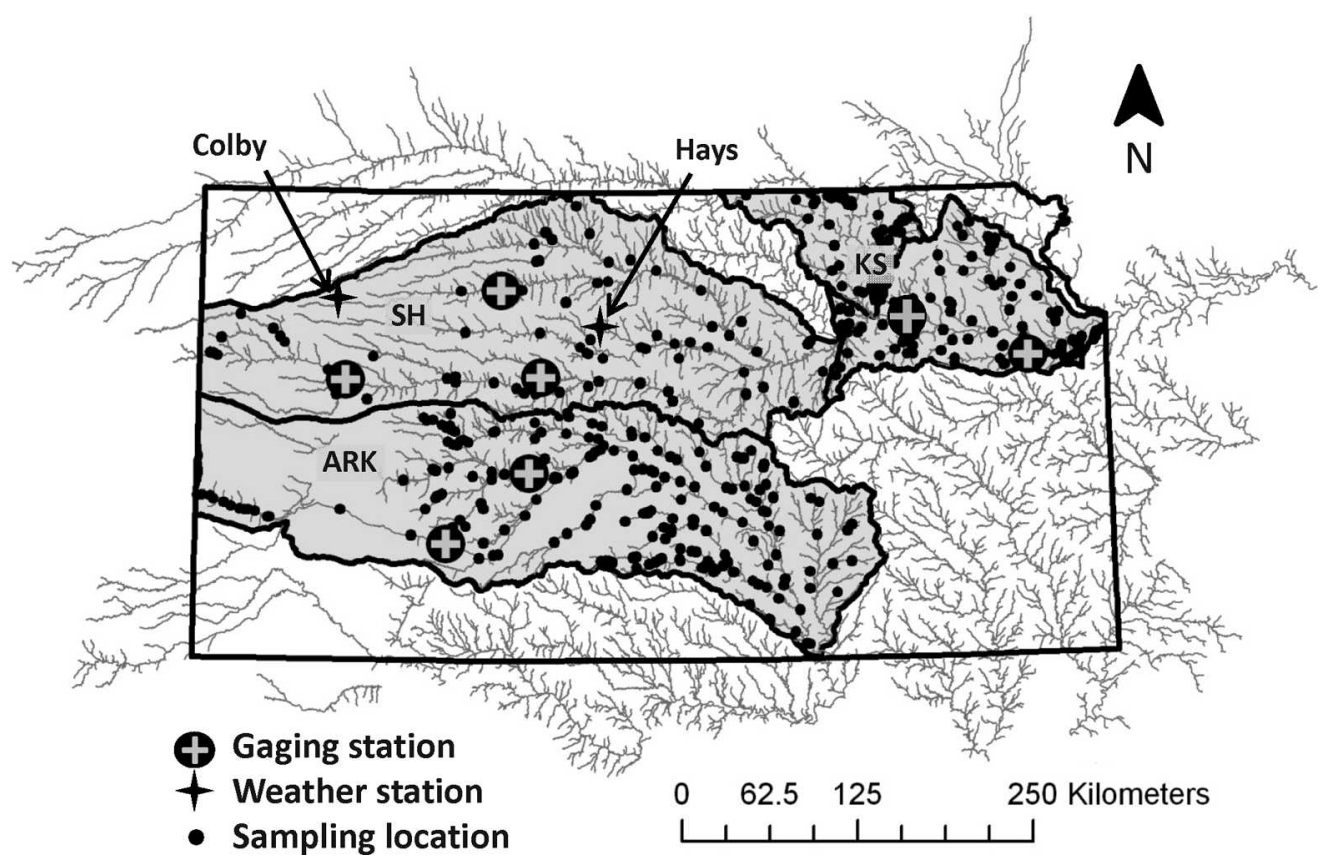

FIG. 1. Map of 3 main river basins ( $\mathrm{SH}=$ Smoky Hill, ARK = Arkansas, $\mathrm{KS}=$ lower Kansas River) in Kansas with locations of fish sampling sites and streamflow gaging stations operated by the US Geological Survey. Temperature and precipitation data were taken from stations at Hays and Colby, Kansas.

http:/ / www.icpsr.umich.edu/PLAINS/index.html; Gutmann 2006) for years between 1885 and 2005. Farmland was classified as land used for practices that generally require no irrigation (i.e., pasture, range, and fallow) and land used for activities that often require irrigation on the Great Plains (i.e., row crops, such as corn, wheat, and sorghum).

Historical annual hydrology data were obtained from the US Geological Survey (USGS; http:// waterdata.usgs.gov/ks/nwis/sw). Representative gaging stations were selected from the Smoky Hill River, Arkansas River, and the lower Kansas River basins to quantify temporal trends in streamflow. Patterns described from these stations are consistent with regional trends in hydrology (Aguilar 2009). A 5y running average was used to separate long-term patterns from relatively high levels of interannual variability.

Historical climate records were used to evaluate regional climate shifts that could have resulted in hydrological changes. Hydrological change primarily affected western Kansas, so continuous precipitation and temperature records were used from 2 stations in the Smoky Hill River basin: 1) Colby, Kansas (Kansas Weather Data Library 2006; period of record 18852003) $\sim 50 \mathrm{~km}$ north of the USGS Elkader gaging station and 2) Hays, Kansas (Heinrichs 2006; period of record 1867-1999) 125 km northeast of the Elkader gaging station. Hundred-year precipitation data
(1895-1993) also were available for nearby counties (Thomas, Wallace, and Greeley; downloaded from records compiled by ICPSR; http://www.icpsr. umich.edu/ PLAINS/index.html; Gutmann 2006).

\section{Historical fish data}

Fish collections between 1947 and 2003 included 1127 community samples (presence-absence) with 93 total species in Kansas (Table 1). Native fish were identified from historical accounts (Hay 1887, Cross 1967, Cross et al. 1986), and these data were supplemented with additional historical records (Eberle 2007). Most historical fish collection records (prior to 1991) were taken directly from field notes of Frank Cross, who began collecting in Kansas in 1951, but these data were supplemented by collection records provided by the University of Kansas Natural

TABle 1. Number of fish collections available for each river basin in each time period. Numbers in parentheses are the mean number of fish species collected per sample during each period.

\begin{tabular}{lrcc}
\hline \hline Time period & Smoky & Arkansas & Lower Kansas \\
\hline $1947-1962$ & $22(9)$ & $34(9)$ & $79(9)$ \\
$1963-1977$ & $12(7)$ & $23(9)$ & $52(10)$ \\
$1978-1990$ & $26(7)$ & $71(8)$ & $64(12)$ \\
$1991-2002$ & $147(8)$ & $370(12)$ & $277(13)$ \\
\hline
\end{tabular}




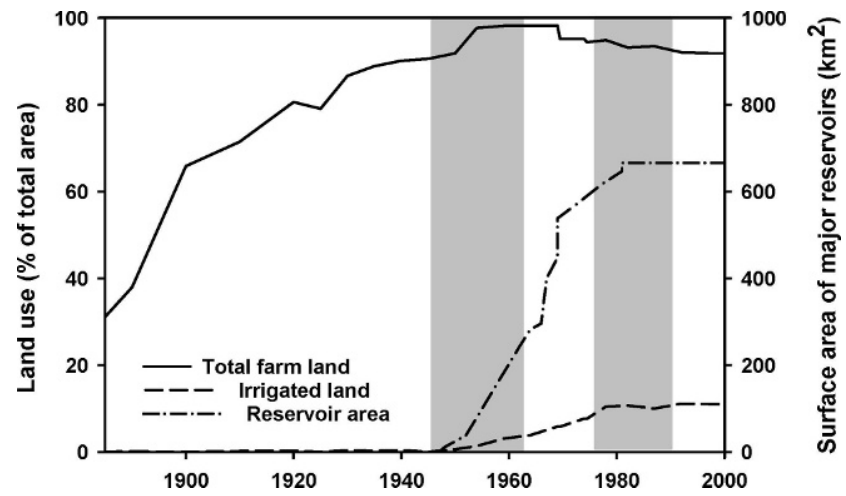

FIG. 2. Trends in land use and cumulative reservoir surface area in the Central Great Plains. Percentages of total farm land were estimated with data from Greeley, Logan, Sherman, and Wallace Counties, Kansas. Percentages of irrigated farmlands were estimated with data from the entire state of Kansas. Cumulative surface area of reservoirs includes only major reservoirs $\left(>10 \mathrm{~km}^{2}\right)$ constructed in Kansas. No records are available for the period before 1880, so the values represent the best available estimate for presettlement conditions. Alternating grey and white background represent time periods used in analysis of fish communities.

History Museum and Sternberg Museum of Natural History. Recent records were based primarily on surveys by the Kansas Department of Wildlife and Parks, supplemented by various collectors with other governmental agencies and universities.

\section{Data analysis}

Our main objective was to quantify the patterns of change in fish communities across time periods that represented major shifts in stream conditions, specifically land use (Fig. 2) and hydrology (Fig. 3A-C). We included 1885 to 1946 in Fig. 2 to illustrate the conversion of native grassland to agriculture, a change that coincides with notable changes in fish communities in the Great Plains before the periods evaluated in our analysis (Cross and Moss 1987, Eberle 2007). Prior to 1947 , hydrology of streams was presumed to be relatively natural, but increasing coverage of dryland farming probably increased sediment loads in streams (Cross and Moss 1987, Eberle 2007). In the period 19471962, both reservoir construction and irrigation agriculture began at low levels. Flow quantity and variability were similar to historical conditions during this period (Fig. 3A-C). In the period 1963-1977, surface area of major impoundments increased rapidly and percentage of irrigated land (primarily in western Kansas) increased steadily to current levels. Stream discharge in the Smoky Hill River basin and parts of the Arkansas River basin generally decreased in quantity

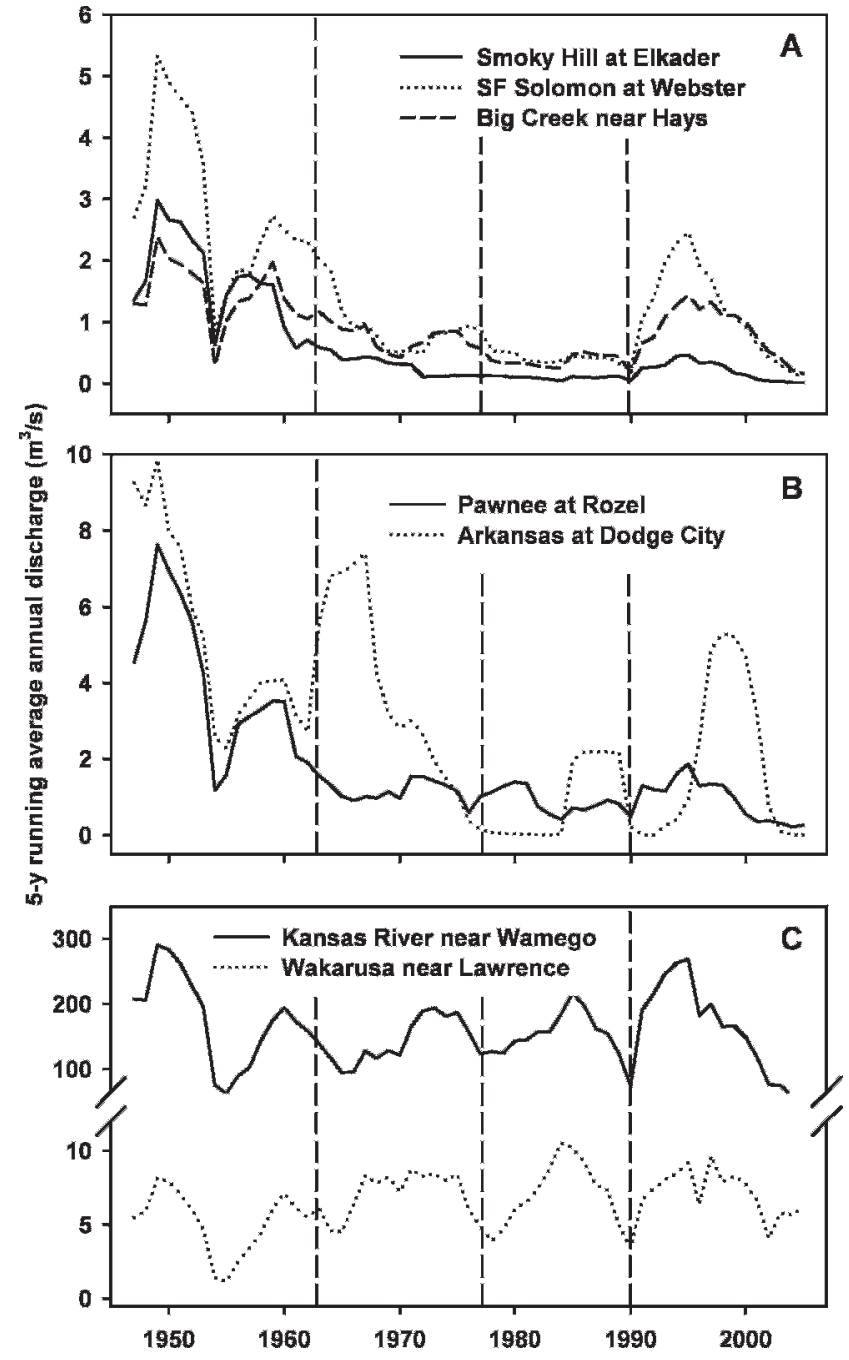

FIG. 3. Temporal changes in 5-y running average annual discharge for representative US Geological Survey gaging stations in the Smoky Hill River basin (A), upper Arkansas River basin (B), and eastern Kansas (C). Vertical dashed lines delineate time periods used in analysis of fish communities.

and variability relative to the eastern Kansas streams. The period after peak groundwater withdrawal and reservoir construction was divided into 2 periods, 1978-1990 and 1991-2003, to stratify historical sampling and to examine the possible lag time between onset of these stressors and effects on fish communities.

Our historical data set did not represent equal collecting effort within time periods or across regions (Table 1). To avoid potential bias with sampling effort, a rarefaction approach (Gotelli and Graves 1996) was used to evaluate temporal changes in species richness. This approach evaluated the change in cumulative species richness with increasing numbers of samples in a given time period. Although the 
TABle 2. Watershed characteristics for Kansas, including average annual rainfall (mm; Kansas State University Weather Library) and potential human stressors. Potential stressors include \% farmland that is irrigated (Interuniversity Consortium for Political and Social Research; http://www.icpsr.umich.edu/PLAINS/index.html; Gutmann 2006), number of large reservoirs (>1000 ha), \% surface area occupied by all impoundments, and population density (average number of people/county; US Census 2000; www.census.gov).

\begin{tabular}{|c|c|c|c|c|c|}
\hline \multirow[b]{3}{*}{ Basin } & \multirow[b]{3}{*}{ Annual precipitation (range) } & \multicolumn{4}{|c|}{ Perturbation } \\
\hline & & \multirow[b]{2}{*}{ Irrigation $(\%)$} & \multicolumn{2}{|c|}{ Impoundments } & \multirow[b]{2}{*}{ Population density } \\
\hline & & & Large (count) & All $(\%)$ & \\
\hline Smoky Hill River & $420-680$ & 2.0 & 6 & 0.3 & 9300 \\
\hline Upper Arkansas River & $290-680$ & 11.0 & 2 & 0.5 & 25,000 \\
\hline Kansas River & $680-1340$ & 0.1 & 14 & 1.5 & 35,000 \\
\hline
\end{tabular}

initial slope of that relationship might be expected to be steeper (i.e., faster accumulation of species) with greater sampling effort and efficiency per collection, the asymptote should occur at the same point if enough samples were taken to represent the number of species present in that basin. A Monte Carlo simulation with 10,000 iterations, which randomized the order in which collections were taken, was used to characterize the relationship between number of collections and cumulative species richness. Comparisons among periods were made based on the cumulative species richness after the minimum number of collections in the period with the fewest collection records.

Changes in species composition (presence/absence) were assessed with Jaccard's dissimilarity index to estimate community divergence across the 4 periods for each basin. Jaccard's dissimilarity index ranges from 0 to 1 , where a value of 1 indicates no shared species and a value of 0 indicates identical species composition. An unweighted pair-group method averaging (UPGMA) clustering algorithm was used to organize periods based on assemblage dissimilarity.

Because of the uneven distribution of sampling effort among periods, a randomization procedure was used to evaluate changes in the $\%$ of sites in which a species occurred across time periods. In this procedure, a subset of the collections within each period was drawn randomly without replacement, and the \% of collections with that species was calculated. The number of samples drawn was $80 \%$ of the number of collections in the period with the least number of collections. For example, in the Arkansas River basin, the fewest collections for any period was 23 between 1963 and 1977. Therefore, we randomly selected 18 collections from each period to calculate the $\%$ of sites occupied by each species. This procedure was repeated 1000 times, and means and 95\% confidence intervals were calculated for each time period. We assumed that if confidence intervals did not overlap, the occurrence of that species had significantly increased or decreased across time periods. A species was classified as declining or increasing only if the trend was consistent across the 4 periods. That is, trends were not considered to be significant for species that declined but then increased or those that increased but then declined.

\section{Results}

\section{Land use among basins}

Levels and type of human alterations varied among basins (Table 2). The upper Arkansas River basin was affected primarily by groundwater withdrawals. The Smoky Hill River basin was affected by impoundments and, to a lesser degree, groundwater withdrawals. The lower Kansas River basin was affected by impoundments, but maintained base flow because of less irrigation and greater annual precipitation. All of the basins were affected by row-crop agriculture.

Land use differed among basins, but temporal trends were similar among basins. A steady increase in area of land in cultivated agriculture in Kansas, as represented by data from western counties (Thomas, Greeley, Wallace), began in 1885 and stabilized by the 1960s, when most of the arable land was farmed (Fig. 2). This trend was consistent with patterns described by Parton et al. (2007) for the entire Great Plains. Prior to 1870, land use in western Kansas was essentially all open range with grazing by native species, especially bison. From 1885 to 1947, 47\% of total land area was converted from open range into summer-planted row crops (corn and grain sorghum), winter wheat, and other annual small grains. The presence of irrigated lands began in the 1950s and peaked in the late 1970s. Temporal trends in the construction of large reservoirs mirrored those for 
irrigated lands, thus making it difficult to uncouple the response of fish communities to these stressors.

\section{Hydrological changes}

Substantial changes have occurred in streamflow patterns in western Kansas, especially since the mid1960s (Fig. 3A, B). In the Smoky Hill River and upper Arkansas River basins, mean daily discharge generally declined over time. Since the mid-1970s, a number of streams (e.g., Arkansas River at Dodge City and Smoky Hill River at Elkader) have ceased flowing for $>350 \mathrm{~d}$ of the year (data not shown). Streamflow patterns in eastern Kansas streams did not show declining trends in annual mean discharge (Fig. 3C), but it is likely that impoundments have altered the timing and possibly intra-annual variability of flows in some streams. These trends probably were not associated with climate. Mean annual precipitation ranged from 390 to $570 \mathrm{~mm}$ near Colby, Kansas, and 234 to $1101 \mathrm{~mm}$ near Hays, Kansas, with no significant trend. Temperature ranged from 10.6 to $11.9^{\circ} \mathrm{C}$ near Colby and 9.6 to $13.6^{\circ} \mathrm{C}$ near Hays. No trend was observed for temperature near Colby, but mean annual temperature near Hays has increased by $\sim 1^{\circ} \mathrm{C}$ in the past century (Heinrichs 2006). More significantly, the extremely low precipitation associated with the dustbowl (1930s) and the strong drought in the 1950s did not lead to stream drying as extensive as is occurring now under normal precipitation.

\section{Fish community structure}

The number of species per collection has increased in the lower Kansas River and Arkansas River basins, but no trend was detected in the Smoky Hill River basin (Table 1). Temporal patterns of increasing species richness per collection varied across basins (Fig. 4A-C). In the Smoky Hill River and Arkansas River basins, the fastest rate of accumulation of species occurred in the most recent period, but the difference in cumulative species after 20 collections was much greater in the Arkansas River basin (11.2 vs 4.3 more species; Fig. 4A, B). In contrast, the rate of accumulation of species per collection was lowest in the 1991-2003 period for the lower Kansas River basin (7.6 fewer species after 20 collections compared to collections in the 1978-1990 period; Fig. 4C). These data suggest a general increase in species richness in western Kansas basins. Although the number of species per collection increased in the lower Kansas River basin, the cumulative number of species in the basin has declined.

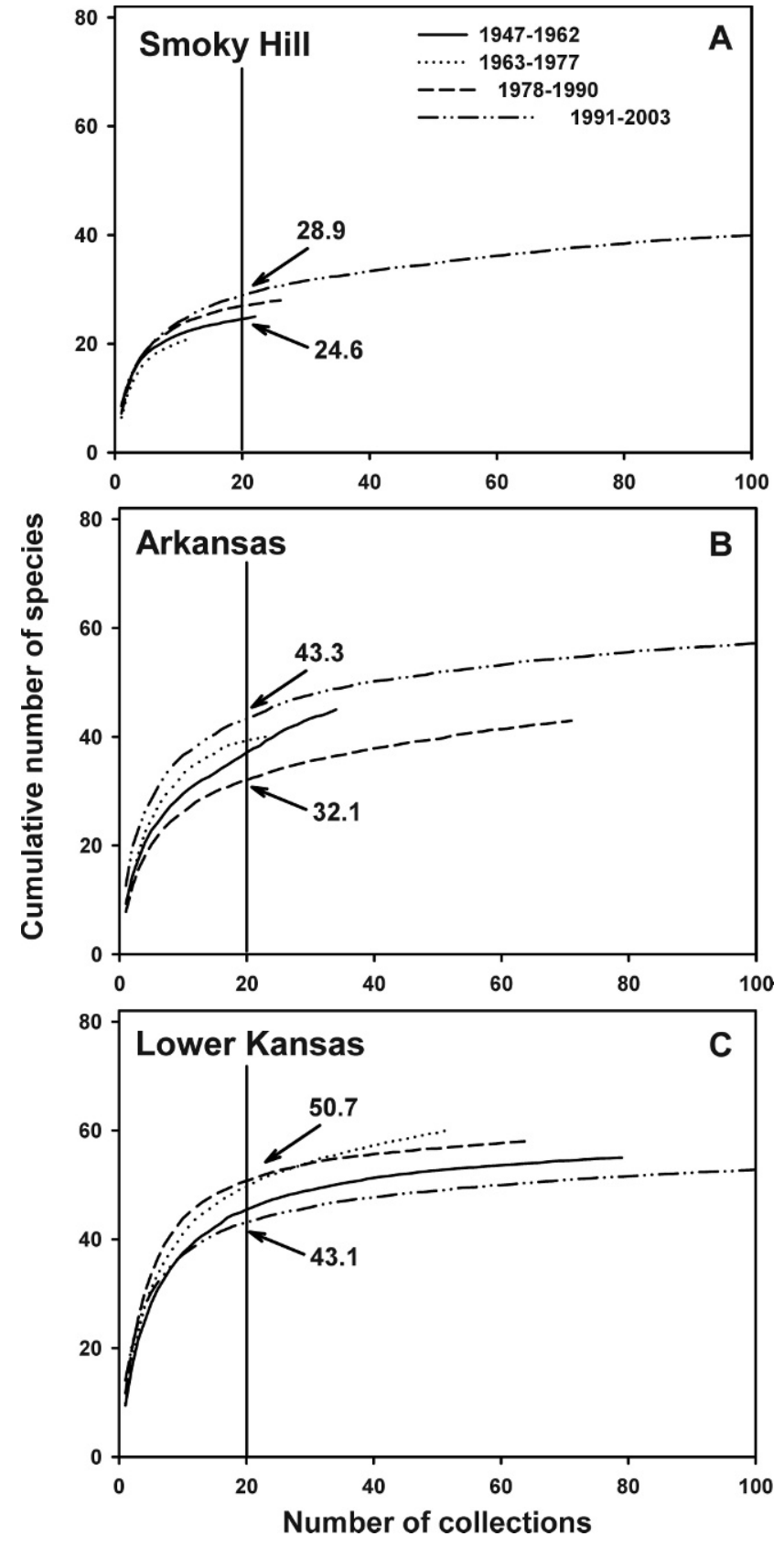

FIG. 4. Rarefaction curves describing the cumulative species richness vs the number of sites visited for designated time periods for the Smoky Hill River basin (A), upper Arkansas River basin (B), and lower Kansas River basin (C). Vertical lines and numbered arrows represent the estimated mean number of species collected after 20 samples (only maximum and minimum values are given).

Analysis of assemblage dissimilarity showed a more pronounced change in fish assemblages in western Kansas basins than in the lower Kansas River basin (Fig. 5A). In the Smoky Hill River basin, fish community composition generally has diverged with 
A. All species
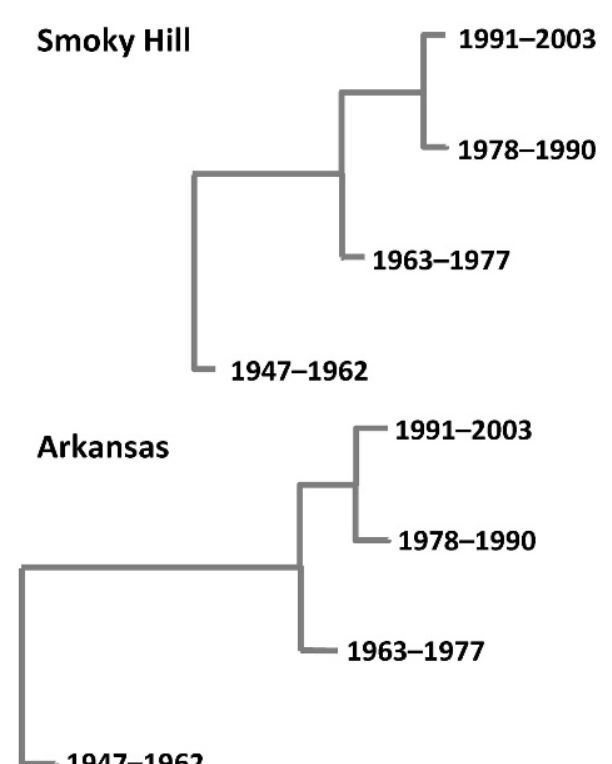

B. Natives only
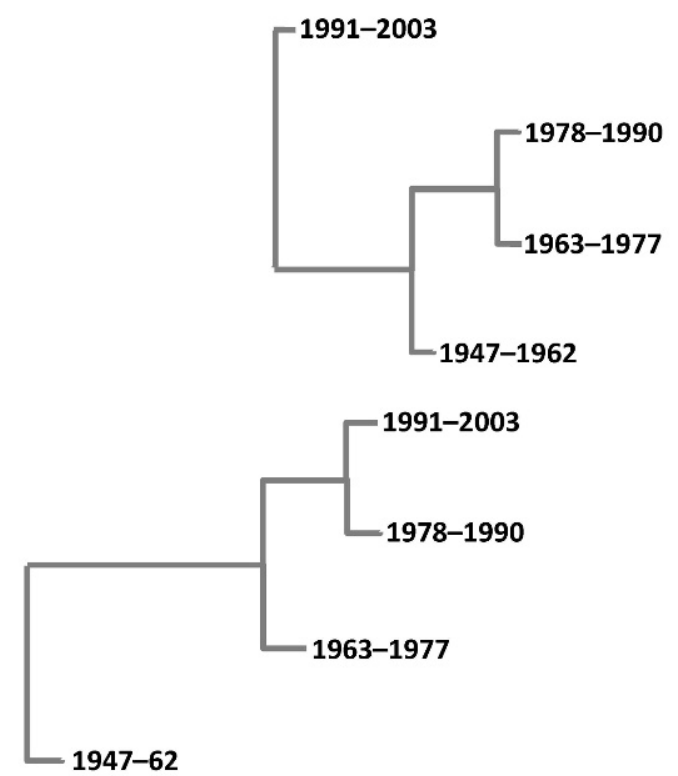

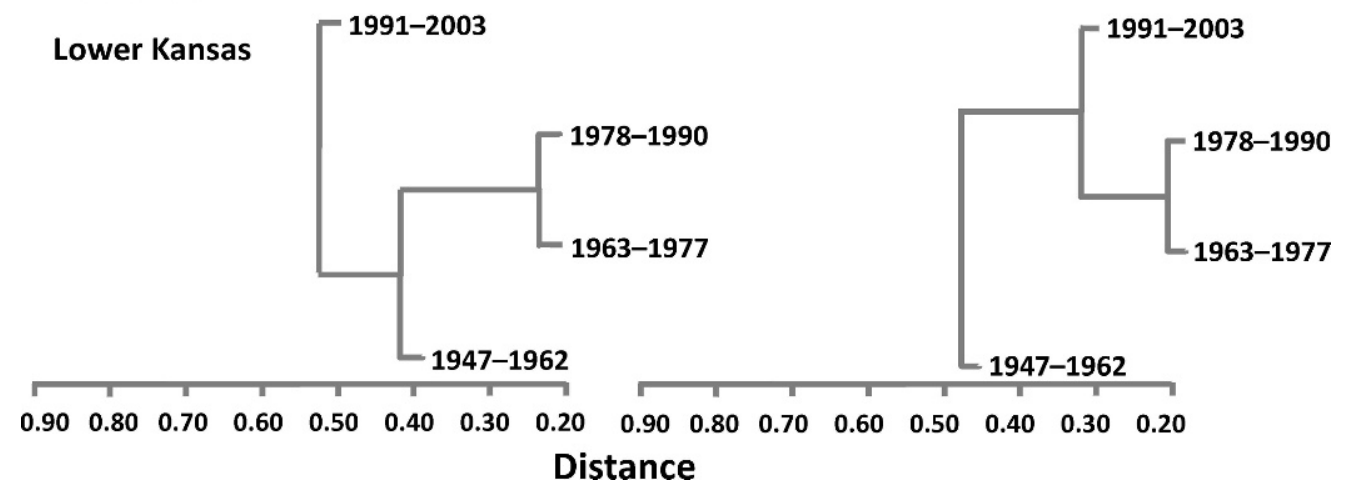

FIG. 5. Dendrograms representing fish community similarity based on all species sampled (A) and native species only (B) across time periods for the Smoky Hill River basin, upper Arkansas River basin, and eastern Kansas based on Jaccard's index of dissimilarity. Jaccard's indices for each year class were calculated using mean resampling procedure to control for uneven sampling across year classes.

time, and the greatest difference among periods was between the 1947-1962 period and the other periods. However, when invasive species were removed from the analysis, this early period was no longer as divergent from other periods (Fig. 5B). The change in community similarity between the 1947-1962 period and more recent periods was greater in the Arkansas River basin than in the Smoky Hill River basin, and this pattern was not heavily influenced by invasive species (Fig. 5A, B). In the lower Kansas River basin, the 1991-2003 period was most different from the other periods when invasive species were included, whereas the 1947-1962 period was most divergent without including invasives, a result suggesting a combined effect of invasive species and alteration of native fish communities (Fig. 5A, B).
Changes in fish species occurrence over time

Changes in species occurrence patterns across periods were greatest in the lower Kansas River basin and least in the Smoky Hill River basin. However, because the number of species that changed significantly was correlated with sampling effort, our statistical power probably was not adequate to evaluate individual species changes in the Smoky Hill River basin, which had the lowest collecting effort. Nevertheless, significant results and trends from this basin were consistent with patterns of change in the other 2 basins.

In the Smoky Hill River basin, 3 species $(11.1 \%$ of native species) showed a significant decline in the $\%$ of sites occupied, and no species showed a consistent 


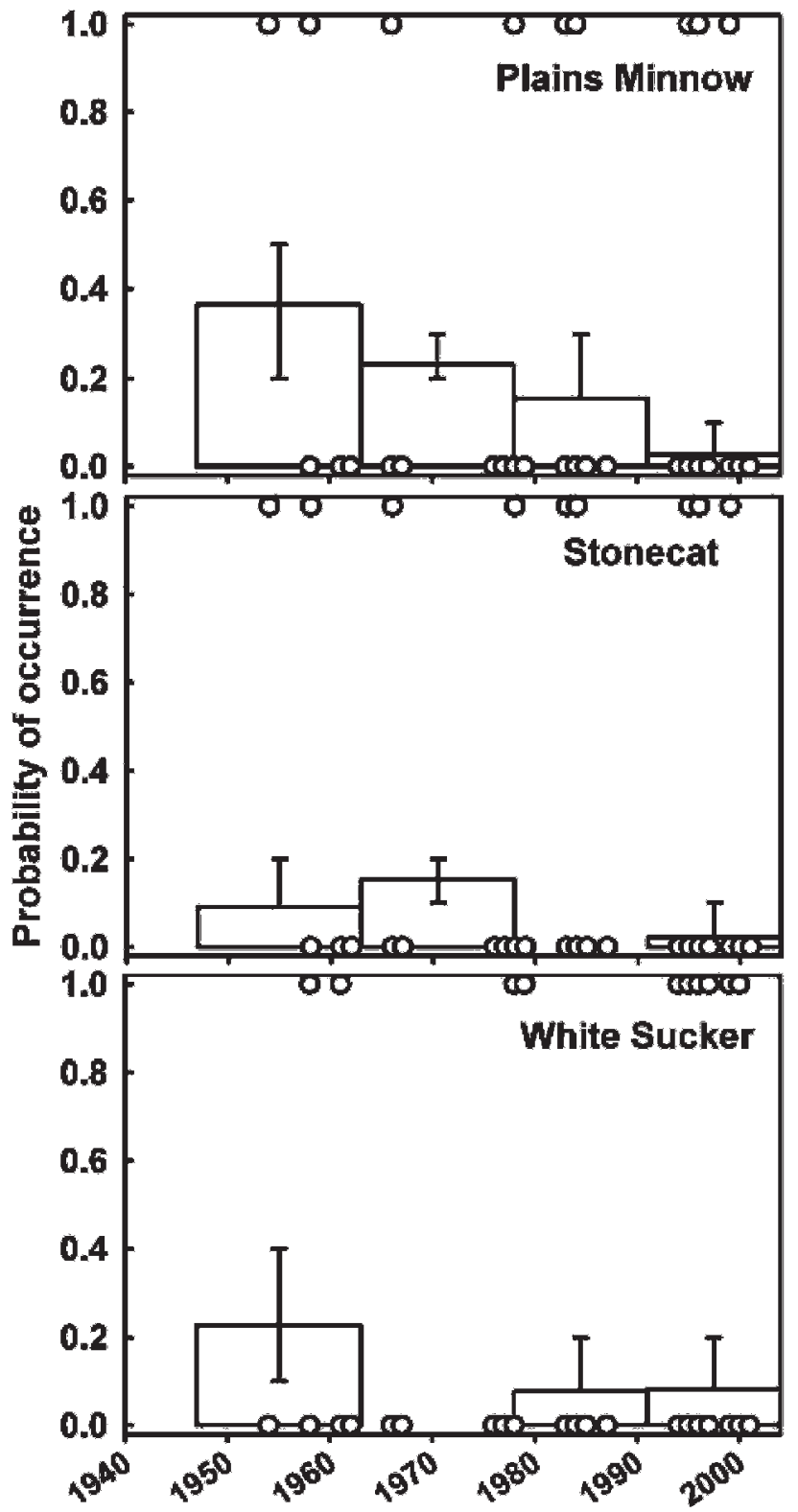

FIG. 6. Temporal changes in fish species occurrence in the Smoky Hill River basin showing mean probability of capture per sample site $( \pm 95 \%$ confidence interval $)$ per time period. Only species showing significant decreasing or increasing trends are presented. Historical presence (open circles where $y=1.0$ ) and absence (open circles where $y=$ 0.0 ) are shown, but multiple presences within a single year are obscured. See Appendix for species scientific names.

pattern of increasing its distribution across time periods (Fig. 6, Appendix). Of the 3 declining species, only the plains minnow showed a pronounced pattern of decline. Other species showed a significant decline in occurrence patterns between the 1947-1962 period and intermediate periods, but these species increased again in later sampling periods (Fig. 6, Appendix).

In the Arkansas River basin, occurrences of 6 species (12.2\% of native species) showed significant decreasing trends, and 7 species had significant increasing trends over time (Appendix). Of the species that showed consistent patterns of decline with time, 4 (shoal chub, carmine shiner, Arkansas River shiner, and river shiner) were not captured in the most recent period, despite extensive sampling (Fig. 7A). Increasing species generally were from the families Ictaluridae and Centrarchidae, and the rate of increase was generally greatest between the 19771990 and 1991-2003 periods (Fig. 7B).

In the lower Kansas River basin, 14 species declined (21.5\% of native species) and 18 species increased in occurrence. As in the Arkansas River basin, shoal chub, plains minnow, flathead chub, river shiner, and carmine shiner all declined (Fig. 8A), and several other species, including silver chub, sturgeon chub, and western silvery minnow, were absent in the 19912003 period. As in the Arkansas River basin, ictalurids and centrarchids were the species most likely to show increasing trends in occurrences in the lower Kansas River basin (Fig. 8B), and several species showed a notable increase in occurrence after 1991.

\section{Discussion}

Regional pattern of change in fish communities

Other authors have noted regional declines for many of the prairie-river species for which we quantified patterns of decline (Cross and Moss 1987, Eberle 2007). Our analysis built on these studies by quantifying changes across basins with different levels of human impacts, by incorporating recent trends in community structure, and by a more rigorous analysis of sampling effects. Perhaps the most alarming result from our analysis was the general decline in occurrence of several species of prairie-river fishes across all basins, including the lower Kansas River basin, which has maintained a relatively stable flow regime. In addition, whereas Cross and Moss (1987) noted declines in these species through the 1980s, our data show that some of these species have virtually disappeared from these basins (e.g., flathead chub, silver chub), and the \% occurrence of invasive species has increased rapidly since 1991. The steady decline to extirpation for many of these species in the past $50 \mathrm{y}$ illustrates the timelagged response of stream fishes to some system perturbations. 


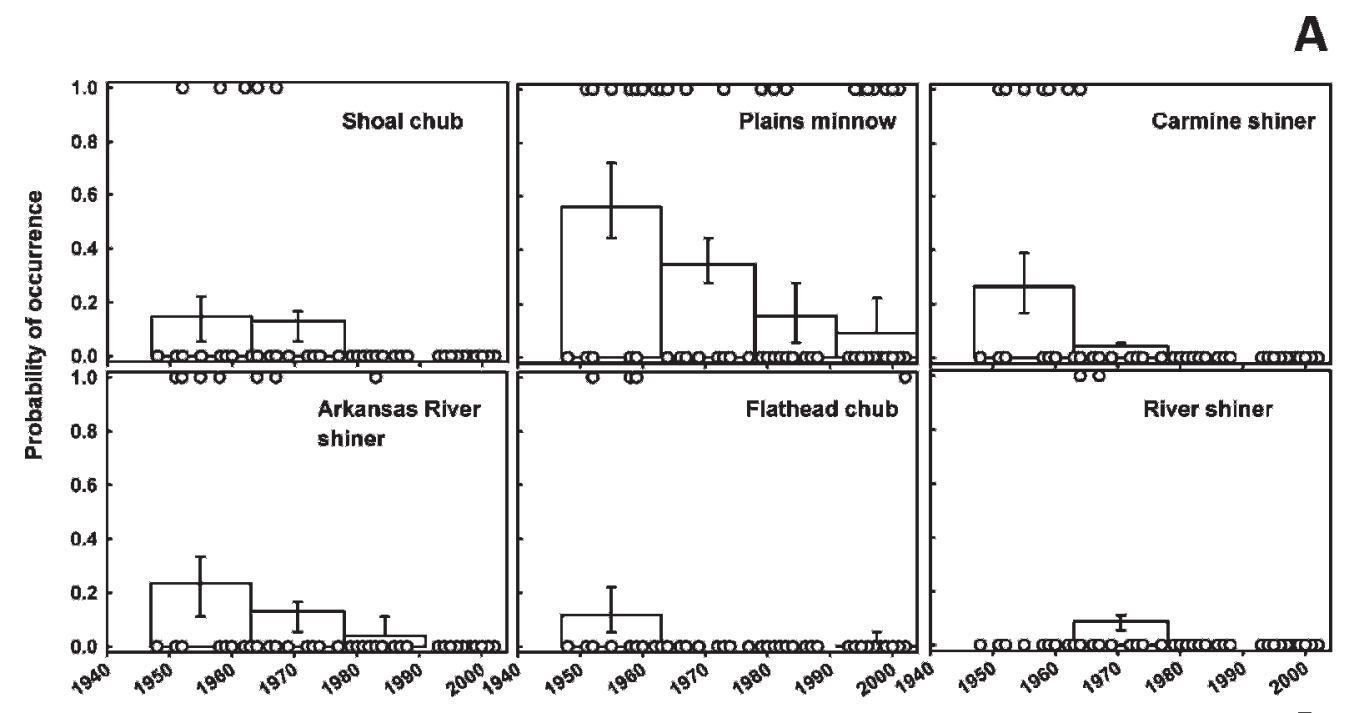

B

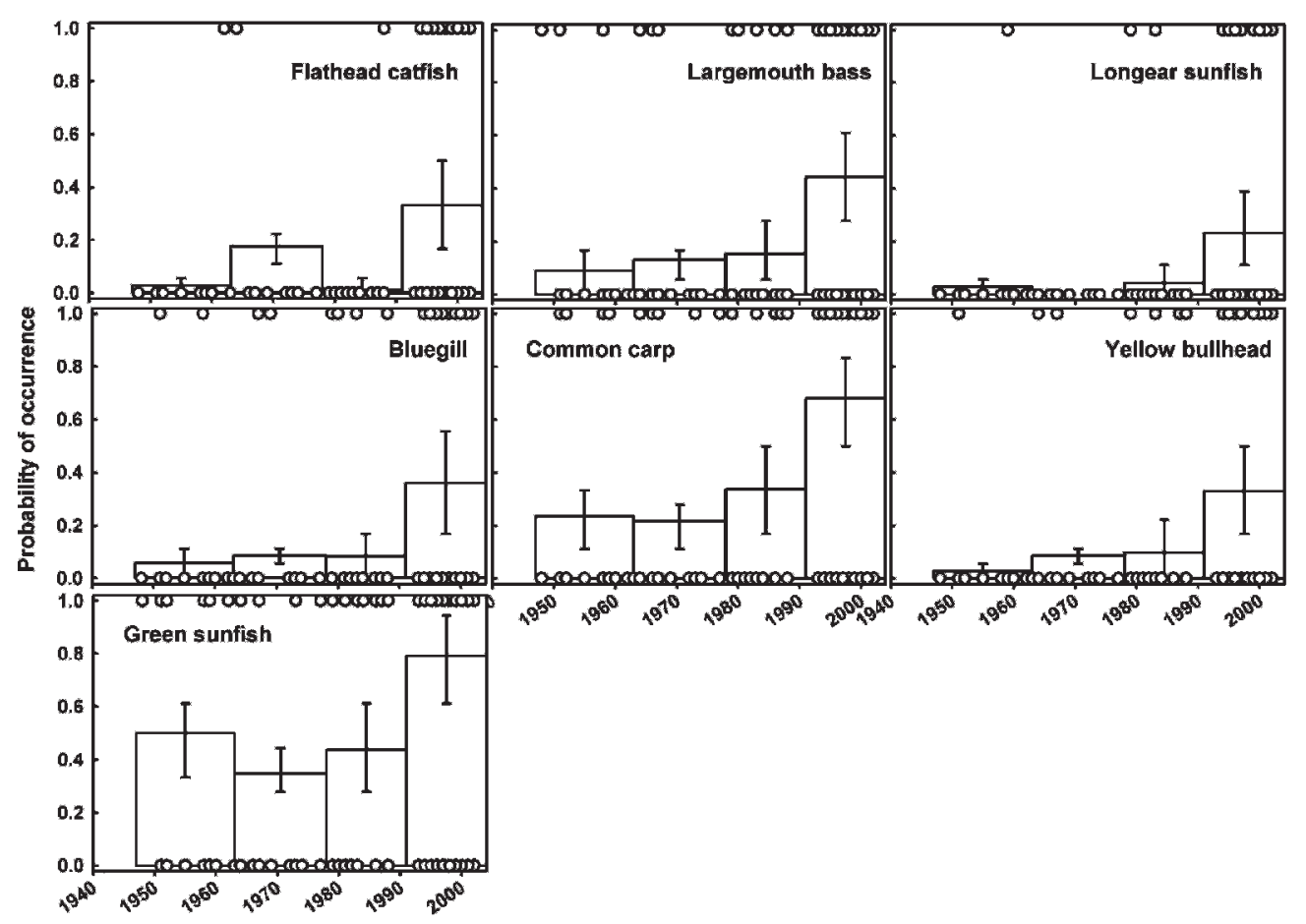

FIG. 7. Temporal changes in fish species occurrence in the Arkansas River basin showing mean probability of capture per sample site ( $\pm 95 \%$ confidence interval) per time period for species showing significant decreasing (A) and increasing (B) trends. Historical presence (open circles where $y=1.0$ ) and absence (open circles where $y=0.0$ ) are shown, but multiple presences within a single year are obscured. See Appendix for species scientific names.

Up to $20 \%$ of the native species in these river basins were detected as declining over the past $1 / 2$ century, and most of these taxa have unique reproductive strategies adapted to prairie river systems. The plains minnow is representative of this regional trend and has declined in all 3 basins. Four more species have declined in both the Arkansas and lower Kansas River basins. With the exception of carmine shiner, these species have similar reproductive strategies that include broadcasting neutrally buoyant eggs that require long, continuous stream habitat for successful development into the current (Battle and Sprules 1960, Donald et al. 1980, Platania and Altenbach 1998, Luttrell et al. 1999). These species have been extirpated upstream from reservoirs as a direct result of their requirement for continuous river sections for success- 

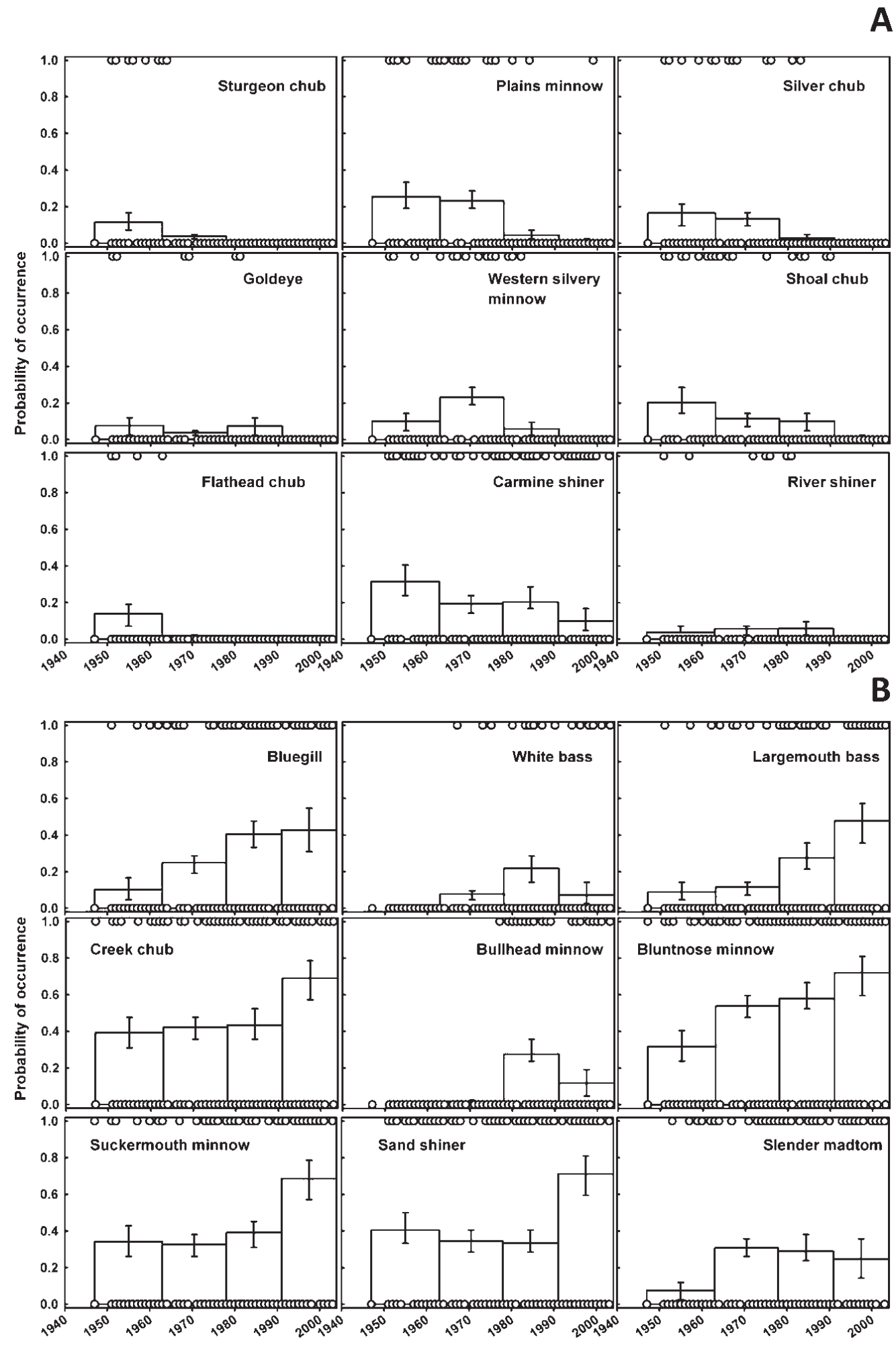

FIG. 8. Temporal changes in fish species occurrence in the lower Kansas River basin showing mean probability of capture per sample site ( $\pm 95 \%$ confidence interval) per time period for species showing significant decreasing $(A)$ and increasing (B) trends. Historical presence (open circles where $y=1.0$ ) and absence (open circles where $y=0.0$ ) are shown, but multiple presences within a single year are obscured. See Appendix for species scientific names. 
ful recruitment (Winston et al. 1991, Gido et al. 2002). In general, spawning modes, such as broadcasting eggs and less parental care, are related to reduced success rates in streams with altered flow and sediment regimes (Johnston 1999). Therefore, fish species likely to persist and expand in altered Great Plains streams are predicted to be nonbroadcast spawners, perhaps with parental care, that are cued by temperature or daylight rather than flow conditions to spawn. These species include fathead minnow and several centrarchids. In addition, habitat heterogeneity has declined as peak discharges have declined, thereby reducing or eliminating shallow side channels and backwaters with warmer water temperatures in braided streams that would support rapid growth of juvenile fish (Platania and Altenbach 1998). Fragmentation of river networks and altered channel morphology through impoundments and dewatering probably are major drivers in the decline of these species.

Changes in stream flow probably are not the only stressor affecting the regional fauna. Decreases in turbidity, to which native species are adapted (Bonner and Wilde 2002), probably have facilitated the replacement of native species by sight-feeding invasive species in regional rivers (Cross and Moss 1987). This decline in turbidity below impoundments can increase predation risk for many minnow species (Rahel and Thel 2004). Conversely, increased sedimentation from agricultural practices in the drainages of smaller streams can favor species that are tolerant of habitat degradation and siltation (Palic et al. 2007). Silt tolerance is a life-history trait possessed by many species that are abundant or are increasing across Kansas, including red shiner (Scott and Crossman 1973, Brewer et al. 2006), fathead minnow, bluntnose minnow, bullhead minnow (Johnston and Page 1992), and 2 centrarchid species (green sunfish and orangespotted sunfish; Wainwright and Lauder 1991). Other species, such as carmine shiner, probably are decreasing because of lack of tolerance for turbidity and a requirement of silt-free substrate for spawning (Cross and Collins 1995).

Only a few species expansions were detected in the Smoky Hill basin, but patterns of species expansions were similar between the Arkansas and lower Kansas basins. Moreover, some of the species that expanded in these basins (e.g., largemouth bass, flathead catfish) showed increasing, but not significant, trends in the Smoky Hill basin (Appendix). Not surprisingly, many species expanding their distribution were those of interest to anglers and that have been actively managed. Why some of these species have expanded in recent years is not clear, although it is possible that use of current sampling methods (i.e., electrofishing vs seining) has increased the detection of these species. Alternatively, the presence of these species in Kansas streams is associated with increasing numbers of small impoundments (Falke and Gido 2006, Eberle 2007), so management and transport of these species might have expanded recently.

\section{Differences among basins}

Comparisons of community response across basins could indicate the influence of main perturbations experienced by fishes in this region. The main differences between the Smoky Hill River and Arkansas River basins were the magnitude of change and the influence of invasive species on assemblage similarity. Fish assemblage composition in the Arkansas River basin shifted abruptly after 1962, and this shift was driven primarily by changes in native species occurrence patterns (Fig. 5). In contrast, community composition shifted more gradually in the Smoky Hill River basin, and this shift was driven by changes in both native and invasive species. We hypothesize that abrupt changes in native species in the Arkansas River basin were caused by reductions in streamflow as a result of groundwater extraction, which was extensive in this basin. The Smoky Hill River basin also experienced groundwater reductions, but was more heavily impounded than the Arkansas River basin, a situation that might explain the greater role of invasive fishes in restructuring communities in that basin. We acknowledge the difficulties in using unreplicated, large-scale systems to infer causation, and offer these associations only as hypothesized factors that could have caused different trends in community change among basins.

Basin-wide species richness generally has increased in western Kansas and decreased in eastern Kansas. This result probably occurred because many of the species that expanded into western Kansas were more widely distributed in the lower Kansas River basin prior to 1947. For example, introductions of centrarchids in the Smoky Hill River basin were first recorded following reservoir construction (all first stream reports are from 1966), except the black crappie, which first occurred in 1983. These same species were first recorded in the upper Arkansas River basin in the 1948-1969 period, whereas 3 additional centrarchid species (warmouth, redear sunfish, and spotted bass) were first recorded from the basin in 1995. Basins in eastern Kansas had the earliest (since 1911) and largest numbers of centrarchid introductions, and only the warmouth was newly reported from the basins after 1970. Similarly, 
the western mosquitofish was the only introduced species that occurred prior to reservoir construction in the Arkansas River basin (first recorded in 1941), except one occurrence of the yellow bullhead in 1948. In the lower Kansas River basin, records of first occurrences of introduced species in the rivers were from 1909 (common carp) and were not obviously related to reservoir construction. Thus, the expansion of nonnative species has offset extirpations of native fishes in western Kansas. In contrast, the regional extirpation of species in the lower Kansas River basin was not offset by increases in invasive species over the past $1 / 2$ century; however, the number of species per collection increased because of increased distributions of invasive taxa.

\section{Time lags}

The transition of the fish community dominated by lotic specialists to dominance by generalists might have been a time-lagged response that occurred after the onset of the low streamflow regime. Patterns of decline for some native fishes were gradual (i.e., plains minnow; Figs 6, 7A), whereas others were rapid (e.g., shoal chub in Arkansas River basin; Fig. 7A). Moreover, many invasive species rapidly expanded their distributions in the 1999-2003 period (Figs 7B, 8B). This variability in community response is consistent with the hypothesis that critical threshold levels of habitat condition might drive temporal and spatial patterns of community restructuring (With and Crist 1995). Moreover, time lags between anthropogenic disturbance and ecological effects, coupled with the observed quantity of habitat loss in this system, might represent an extinction debt, defined as the potential loss of future species (the ecological cost) caused by current habitat destruction (Tilman et al. 1994).

Time-lagged response could also occur during the recovery phase of a stream restoration projects, such as water treatment plants, flow modifications, dam removal, or cessation of groundwater pumping. By not considering species that might have declined in their distribution but later increased (e.g., fathead minnow in Lower Kansas River basin), we assumed that no improvements had occurred in these systems and that time-lagged responses were relevant only to species with consistent declining and increasing trends. Relatively recent improvements to the system would not be detected using our methods. However, with the exception of improvements in water quality after the passage of the Clean Water Act in 1977, no evidence exists that stream habitat in this region has improved. Rather, most data suggest a general deterioration with increasing stressors over time.

The magnitude of time lags should be linked to the turnover rates of taxa. Most fishes that we report as declining or increasing in distribution have relatively short life spans (1-5 y). Thus, each time period in our study represents multiple generations of these species, and gradual changes, such as for the plains minnow, indicate that these populations eroded over time rather than having a catastrophic decline. Whether the gradual declines (or increases) are the result of population dynamics or continually changing environment is not clear.

\section{Historical data analysis}

Our data analysis technique consisted of iteratively resampling the same number of collections from each period and was based on the assumption that sampling effort was evenly distributed in the region and over time. However, this method was unable to detect declines of some rare species that have been documented to have declined in this region (e.g., American eel, pallid sturgeon). In addition, more recent efforts could be biased toward collection of species listed as protected or considered for protection by the US Fish and Wildlife Service or Kansas Department of Wildlife and Parks. For example, this bias might explain why Topeka shiner occurrence has an increasing trend in the Smoky Hill River basin (Appendix), but declined in the Kansas River basin. Nevertheless, most of the patterns we described are consistent with previously reported patterns (e.g., Cross and Moss 1987, Eberle 2007), and our approach has allowed us to quantify the transition of the regional fish faunas in relation to these changes to the environment.

\section{Implications for restoration, impetus for conservation}

Can this system be returned to its previous state? The recharge rate of some portions of the High Plains Aquifer is so slow that recovery could take a century or more to reach 1940 levels, assuming that all groundwater withdrawals could be stopped (Sophocleous 2005). However, political, economic, and sociological realities currently determine the extent of groundwater withdrawals. For example, the recent emphasis on biofuels (Kansas Department of Agriculture; www.ksda.gov) has increased the price of corn and, therefore, the incentive to extract groundwater for irrigation in western Kansas. Similar human dynamics affect the likelihood of removing reservoirs to restore network connectivity. Increases in flow 
quantity would probably benefit native fish populations by providing increased connectivity and availability of stream habitats. Whether natural flows would control invasive species, which could influence the recovery of these systems, is not clear. Return of natural flows could create an environment that favors native, fluvial specialists and diminishes populations of nonnative, lentic specialists (Bunn and Arthington 2002). Alternatively, these invasive species, once established, could respond to natural flows in a manner similar to native species.

Hydrology and fish communities have been altered worldwide by major and ongoing anthropogenic perturbations (e.g., Deacon et al. 2007). The magnitude of change observed in these Kansas streams, and elsewhere, probably is the result of the combined effects of a series of perturbations. No major perturbations to streams have begun since the 1970s, but the effect of groundwater withdrawal in western Kansas has increased the number and duration of drying events since that time. Changes in the fish community remain ongoing and long-term because of the regime shift in stream flows and drainage network structure (i.e., time-lag effects of previous perturbations). Modification of habitat coupled with species introductions can strongly affect fish community structure. The abiotic and biotic system might shift as a whole to a regime from which it is difficult to return. Nevertheless, innovative conservation efforts that restore natural flow regimes and hydrologic connectivity and that mitigate impacts of introduced species will be critical to maintaining and potentially restoring these unique fish assemblages.

\section{Acknowledgements}

We thank the Kansas Department of Wildlife and Parks Stream Team, Kansas Heritage, the University of Kansas Museum of Natural History, the Sam Noble Oklahoma Museum of Natural History, and Vaughn Weaver of the Sedgwick County Water Department, Kansas, for providing data for our study. We thank Chris Kowalchuk, Jessica Eichmiller, Michelle EvansWhite, David Hoeinghaus, Craig Paukert, Deb Walks, Kim With, and Jim Koelliker for early discussions and conceptual input on this project. Comments by 2 anonymous referees greatly improved our paper. This work was supported by a US Environmental Protection Agency Science to Achieve Results grant (G4K10783), Kansas Aquatic Gap program funded by the USGS, and Kansas Department of Wildlife and Parks. This is publication 10-365-J from the Kansas Agricultural Experiment Station.

\section{Literature Cited}

Aguilar, J. P. 2009. Historic changes of ecologically relevant hydrologic indices of unregulated Kansas streams. PhD Dissertation, Kansas State University, Manhattan, Kansas.

Battle, H. I., AND W. M. Sprules. 1960. A description of the semi-buoyant eggs and early developmental stages of the goldeye, Hiodon alosoides (Rafinesque). Journal of the Fisheries Research Board of Canada 17:245-266.

BAXTER, R. M. 1977. Environmental effects of dams and impoundments. Annual Reviews in Ecology and Systematics 8:255-283.

Bonner, T. H., AND G. R. WiLDE. 2002. Effects of turbidity on prey consumption by prairie stream fishes. Transactions of the American Fisheries Society 131:1203-1208.

Brewer, S. K., D. M. Papoulias, And C. F. Rabeni. 2006. Spawning habitat associations and selection by fishes in a flow-regulated prairie river. Transactions of the American Fisheries Society 135:763-778.

Bunn, S. E., And A. H. Arthington. 2002. Basic principles and ecological consequences of altered flow regimes for aquatic biodiversity. Environmental Management 30: 492-507.

Cross, F. B. 1967. Handbook of fishes of Kansas. University of Kansas Museum of Natural History, Miscellaneous Publications 45:1-357.

Cross, F. B., AND J. T. Collins. 1995. Fishes in Kansas. $2^{\text {nd }}$ edition. University of Kansas Natural History Museum, Public Education Series Number 14:1-315.

Cross, F. B., R. L. Mayden, And J. D. Stewart. 1986. Fishes in the western Mississippi Basin (Missouri, Arkansas, and Red Rivers). Pages 363-412 in C. H. Hocutt and E. O. Wiley (editors). The zoogeography of North American freshwater fishes. John Wiley, New York.

Cross, F. B., AND R. E. Moss. 1987. Historic changes in fish communities and aquatic habitats in plains streams of Kansas. Pages 115-165 in W. J. Matthews and D. C. Heins (editors). Community and evolutionary ecology of North American stream fishes. University of Oklahoma Press, Norman, Oklahoma.

Deacon, J. E., A. E. Williams, C. Deacon Williams, and J. E. Williams. 2007. Fueling population growth in Las Vegas: how large-scale groundwater withdrawal could burn regional biodiversity. BioScience 57:688-698.

Donald, D. B., R. S. Anderson, And D. W. MayhoOd. 1980. Correlations between brook trout growth and environmental variables for mountain lakes in Alberta. Transactions of the American Fisheries Society 109:603-610.

Dudgeon, D., A. H. Arthington, M. O. Gessner, Z. I. Kawabata, D. J. Knowler, C. Leveque, R. J. Naiman, A. H. Prieur-Richard, D. Soto, M. L. J. Stiassny, and C. A. Sullivan. 2006. Freshwater biodiversity: importance, threats, status and conservation challenges. Biological Reviews 81:163-182.

EberLe, M. E. 2007. Homogenization of fish faunas and concurrent anthropogenic impacts on plains streams in western Kansas: 1854-2003. Fort Hays Studies 4:1-78. 
FAlKe, J. A., AND K. B. Gido. 2006. Spatial effects of reservoirs on fish assemblages in great plains streams in Kansas, USA. River Research and Applications 22: $55-68$.

Gido, K. B., C. S. Guy, T. R. Strakosh, R. J. Bernot, K. Hase, AND M. SHaw. 2002. Long-term changes in the fish assemblages of the Big Blue River basin 40 years after the construction of Tuttle Creek Reservoir. Kansas Academy of Sciences Transactions (Frank Cross Memorial Issue) 105(3-4):193-208.

Gotelli, N. J., and G. R. Graves. 1996. Null models in ecology. Smithsonian Institution Press, Washington, DC.

Gutmann, M. P. 2006. The Great Plains Population and Environment Data: Environmental Data 1870-1997 (Computer file). Inter-University Consortium for Political and Social Research Version, University of Michigan, Ann Arbor, Michigan (producer), Inter-University Consortium for Political and Social Research, Ann Arbor, Michigan (distributor). (Available from: http:// dx.doi.org/10.3886/ICPSR04254)

Hascic, I., AND J. J. Wu. 2006. Land use and watershed health in the United States. Land Economics 82:214239.

HAuer, F. R., AND M. S. LORANG. 2004. River regulation, decline of ecological resources, and potential for restoration in a semi-arid lands river in the western USA. Aquatic Sciences 66:388-401.

HAY, O. P. 1887. A contribution to the knowledge of the fishes of Kansas. Proceedings of the United States Natural History Museum 10:242.

Heinrichs, J. 2006. The climate of Hays, Kansas, from 1867 to 1999: variability, trends, and influences. Fort Hays Studies 2:1-60.

Humphries, P., AND D. S. Baldwin. 2003. Drought and aquatic ecosystems: an introduction. Freshwater Biology 48: 1141-1146.

Jelks, H. L., S. J. Walsh, N. M. Burkhead, S. ContrerasBalderas, E. Diaz-Pardo, D. A. Hendrickson, J. Lyons, N. E. Mandrak, F. McCormick, J. S. Nelson, S. P. Platania, B. A. Porter, C. B. Renaud, J. J. Schmitter-Soto, E. B. TAYLOR, AND M. L. WARREN. 2008. Conservation status of imperiled North American freshwater and diadromous fishes. Fisheries 33:372-407.

Johnston, C. E. 1999. The relationship of spawning mode to conservation of North American minnows (Cyprinidae). Environmental Biology of Fishes 55:21-30.

Johnston, C. E., And L. M. PAge. 1992. The evolution of complex reproductive strategies in North American minnows (Cyprinidae). Pages 600-621 in R. L. Mayden (editor). Systematics, historical ecology, and North American freshwater fishes. Stanford University Press, Stanford, California.

Kinsolving, A. D., And M. B. BAin. 1993. Fish assemblage recovery along a riverine disturbance gradient. Ecological Applications 3:531-544.

Koenn, J. D. 2004. Carp (Cyprinus carpio) as a powerful invader in Australian waterways. Freshwater Biology 49:882-894.
Luttrell, G. R., A. A. Echelle, W. L. Fisher, and D. J. EISENHOUR. 1999. Declining status of two species of the Macrhybopsis aestivalis complex (Teleostei: Cyprinidae) in the Arkansas River basin and related effects of reservoirs as barriers to dispersal. Copeia 1999:981989.

Lytle, D. A., And N. L. Poff. 2004. Adaptation to natural flow regimes. Trends in Ecology and Evolution 19: 94-100.

Nilsson, C., C. A. Reidy, M. Dynesius, and C. Revenga. 2005. Fragmentation and flow regulation of the world's large river systems. Science 308:405-408.

Palic, D., L. Helland, B. R. Pedersend, J. R. Pribil, R. M. Grajeda, A. K. Loan-Wilsey, and C. L. Pierce. 2007. Fish assemblages of the upper Little Sioux River basin, Iowa, USA: relationships with stream size and comparison with historical assemblages. Journal of Freshwater Ecology 22:69-79.

Parton, W. J., M. P. Gutmann, and D. Ojima. 2007. Long-term trends in population, farm income, and crop production in the Great Plains. BioScience 57:737-747.

Platania, S. P., and C. S. Altenbach. 1998. Reproductive strategies and egg types of seven Rio Grande Basin cyprinids. Copeia 1998:559-569.

PofF, N. L., AND J. D. Allan. 1995. Functional organization of stream fish assemblages in relation to hydrological variability. Ecology 76:606-627.

Poff, N. L., J. D. Allan, M. B. Bain, J. R. Karr, K. L. PrestegaArd, B. D. Richter, R. E. Sparks, and J. C. STROMBERG. 1997. The natural flow regime: a paradigm for river conservation and restoration. BioScience 47: 769-784.

Poff, N. L., J. D. Olden, D. M. Merritt, and D. M. Pepin. 2007. Homogenization of regional river dynamics by dams and global biodiversity implications. Proceedings of the National Academy of Sciences of the United States of America 104:5732-5737.

Rahel, F. J., AND L. A. Thel. 2004. Flathead Chub (Platygobio gracilis): a technical conservation assessment. US Department of Agriculture Forest Service, Rocky Mountain Region, Golden, Colorado. (Available from: http:/ / www.fs.fed.us/r2/projects/scp/assessments / flatheadchub.pdf)

Schlosser, I. J. 1987. A conceptual framework for fish communities in small warmwater streams. Pages 17-24 in W. J. Matthews and D. C. Heins (editors). Community and evolutionary ecology of North American stream fishes. University of Oklahoma Press, Norman, Oklahoma.

Scoтt, M. C. 2006. Winners and losers among stream fishes in relation to land use legacies and urban development in the southeastern US. Biological Conservation 127: 301-309.

Scott, W. B., And E. J. Crossman. 1973. Freshwater fishes of Canada. Bulletin of the Fisheries Research Board of Canada 184.

Sophocleous, M. A. 2005. Groundwater recharge and sustainability in the High Plains Aquifer in Kansas, USA. Hydrogeology Journal 13:351-365. 
Tilman, D., R. M. May, C. L. Lehman, and M. A. Nowak. 1994. Habitat destruction and the extinction debt. Nature 371:65-66.

WainWright, P. C., AND G. V. LAUDER. 1991. The evolution of feeding biology in sunfishes (Centrarchidae). Pages 472-491 in R. L. Mayden (editor). Systematics, historical ecology, and North American freshwater fishes. Stanford University Press, Stanford, California.

Winston, M. R., C. M. TAYloR, And J. Pigg. 1991. Upstream extirpation of four minnow species due to damming of a prairie stream. Transactions of the American Fisheries Society 120:98-105.

With, K. A., AND T. O. CRIST. 1995. Critical thresholds in species' responses to landscape structure. Ecology 76: 2446-2459.
Received: 24 August 2009

Accepted: 30 March 2010 


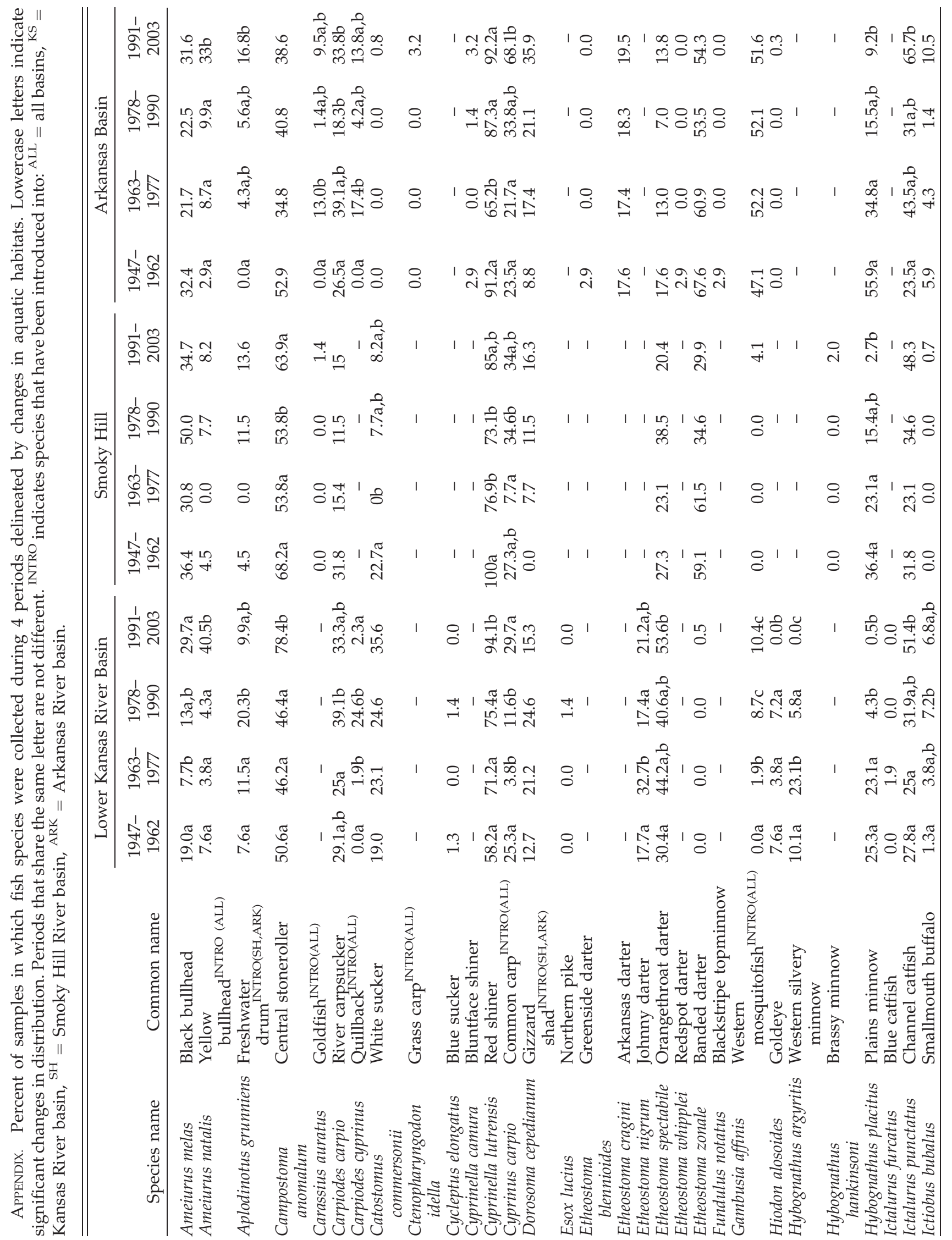




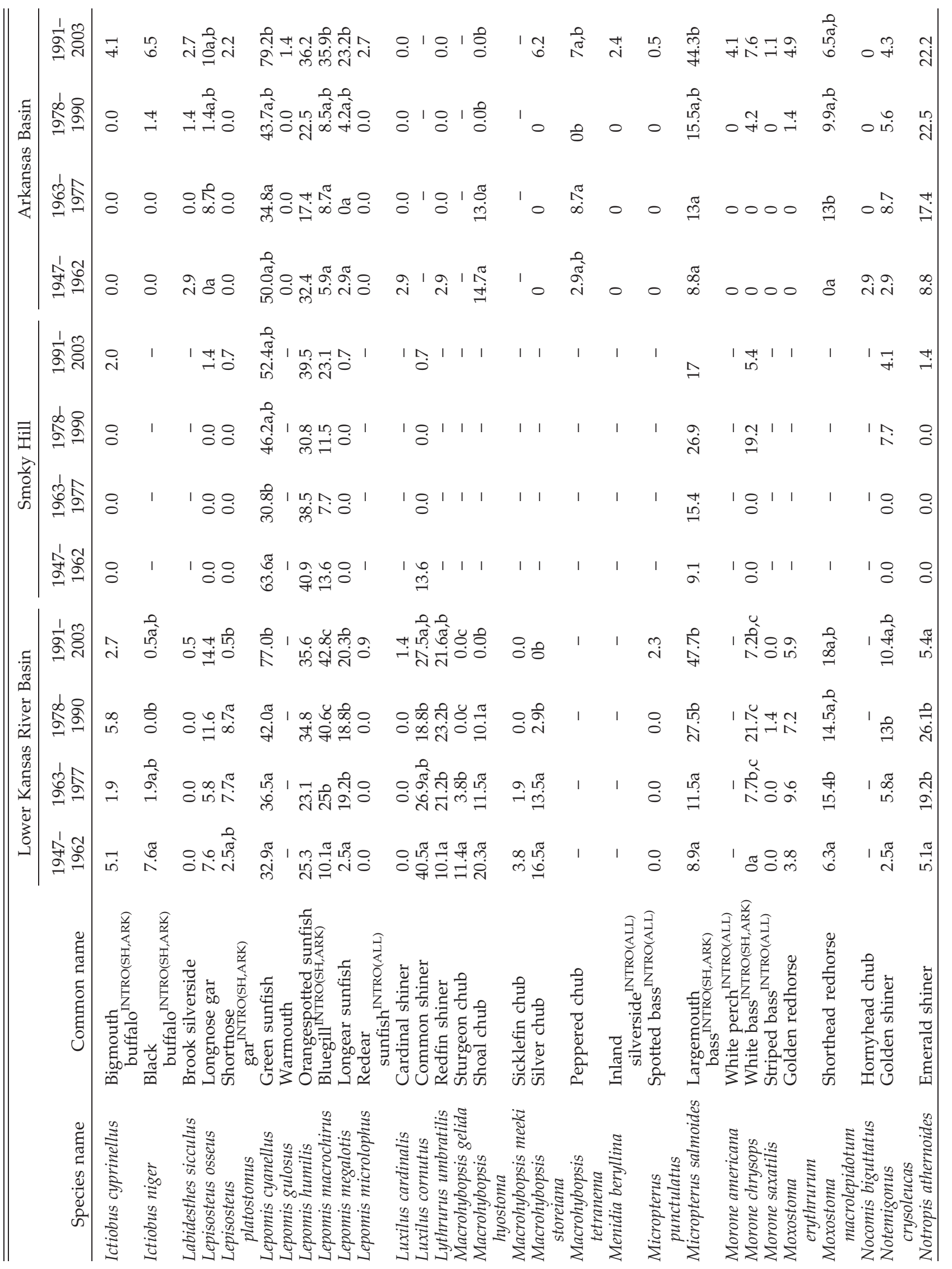




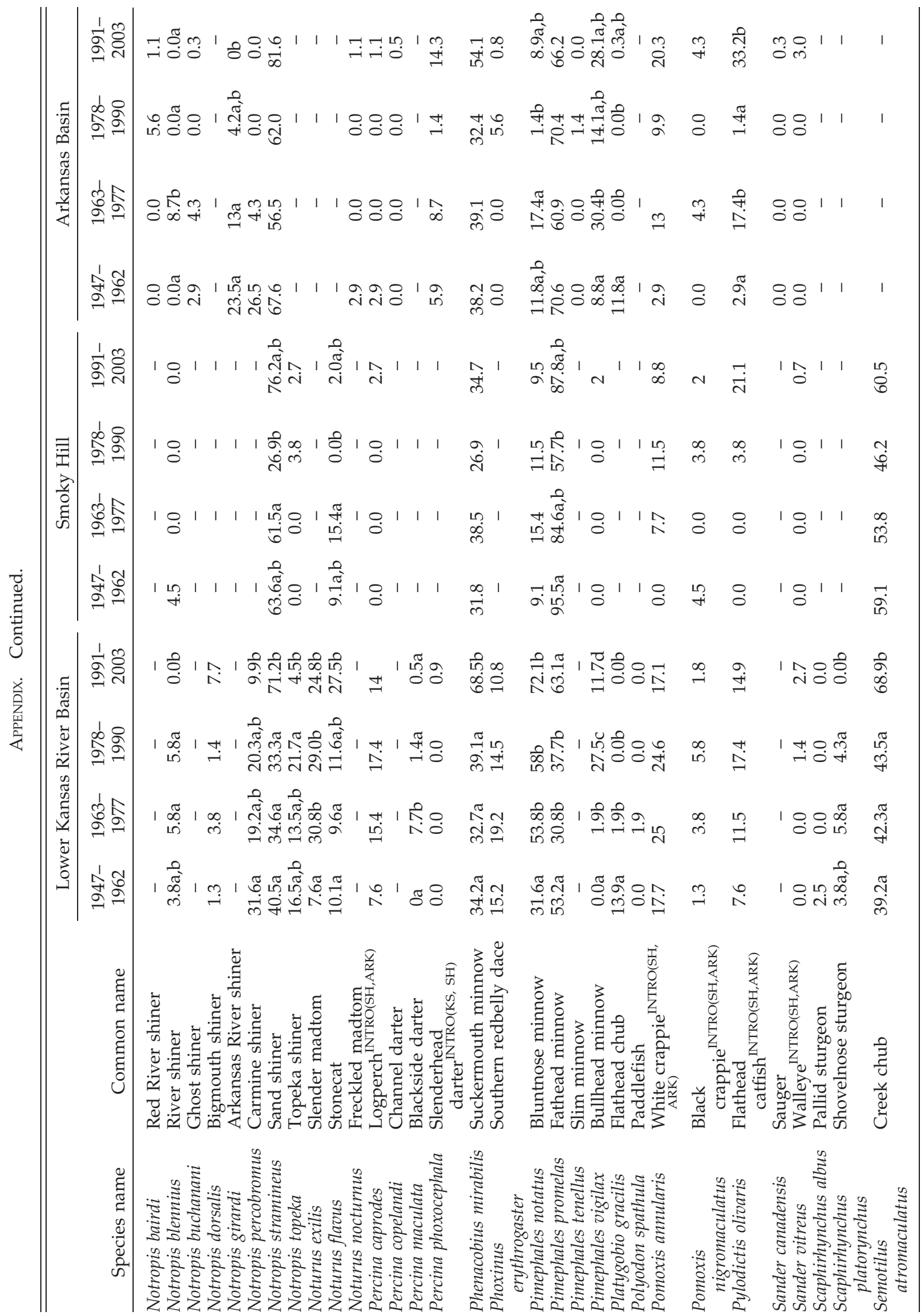

